Supporting information for:

\title{
Isoenzyme-Selective Inhibitors of Human Neuraminidases Reveal Distinct Effects on Cell Migration
}

\author{
Md. Amran Howlader, Tianlin Guo, Radhika Chakraberty, Christopher W. Cairo* \\ Alberta Glycomics Centre, Department of Chemistry, University of Alberta, Alberta, Canada \\ T6G 2 G2 \\ * Corresponding author: ccairo@ualberta.ca, tel. 780-492-0377, fax 780-492-8231
}




\section{Table of contents}

Table S1. Normalized cell migration of HeLa, A549, PC-3 and MDA-MB-231 cells treated with hNEU inhibitors.

Table S2. Normalized cell migration of PC-3 and MDA-MB-231 cells treated with hNEU

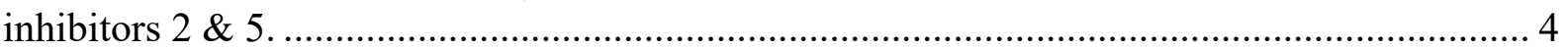

Table S3. Cell migration of simultaneous inhibition of multiple hNEU enzymes in the PC-3 and

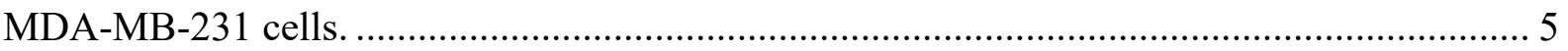

Table S4. Cytotoxicity of hNEU inhibitors. ......................................................................... 5

Table S5: Effect of NEU1, NEU3, and NEU4 knockdown on cell migration........................ 6

Table S6 : Sequences of NEU3 siRNA, NEU1 siRNA, and scrambled control ...................... 6

Table S7. Glycolipid effects on cell migration. ............................................................... 7

Figure S1. Effect of NEU1 overexpression on HEK 293 cell migration................................ 8

Figure S2. Toxicity profile of the PC-3 and MDA-MB-231 cells with inhibitors................... 9

Figure S3. Differential expression levels of NEU3 and NEU1 enzymes. ........................... 10

Figure S4: siRNA Knockdown of NEU1 and NEU3 enzymes in MDA-MB-231 cells. ........ 11

Figure S5: siRNA Knockdown, NEU1 and NEU3 expression levels................................ 12

Figure S6. Glycolipid analysis of PC-3 cells treated with specific inhibitors. ...................... 13

Figure S7: Changes in cell surface sialic acid content by lectin staining. ........................... 14

Figure S8. Changes in cell surface sialic acid content of MDA-MB-231 cells at high inhibitor

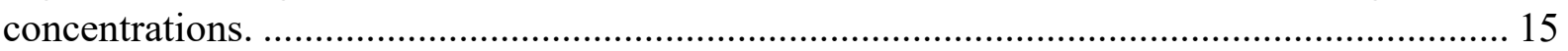

Figure S9: Molecular weight of the $\beta 1$ integrin after neuraminidase treatment................... 15

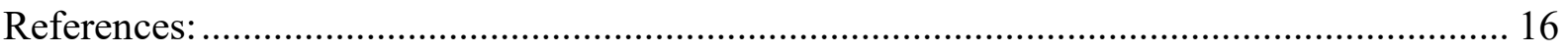


Table S1. Normalized cell migration of HeLa, A549, PC-3 and MDA-MB-231 cells treated with hNEU inhibitors.

\begin{tabular}{|c|c|c|c|c|c|c|c|c|}
\hline & HeLa & & A549 & & PC-3 & \multicolumn{3}{|c|}{ MDA-MB-231 } \\
\hline & Mean \pm SEM & $(\mathrm{N})$ & Mean \pm SEM & $(\mathrm{N})$ & Mean \pm SEM & $(\mathrm{N})$ & Mean \pm SEM & $(\mathrm{N})$ \\
\hline $\begin{array}{r}\text { control } \\
\text { (Buffer) }\end{array}$ & $100 \pm 2$ & (38) & $100 \pm 2$ & (35) & $100 \pm 2$ & (37) & $100 \pm 2$ & (29) \\
\hline $\begin{array}{c}\text { CytoD } \\
(197 \mathrm{nM})\end{array}$ & $38 \pm 2 * * * *$ & (37) & $36 \pm 3 * * * *$ & (34) & $37 \pm 2 * * * *$ & (37) & $24 \pm 1 * * * *$ & (30) \\
\hline $1(100 \mu M)$ & $99 \pm 2$ & $(32)$ & $90 \pm 2 *$ & $(25)$ & $82 \pm 2 * * * *$ & $(27)$ & $91 \pm 2$ & (16) \\
\hline $2(100 \mu \mathrm{M})$ & - & & - & & $167 \pm 8 * * * *$ & $(6)$ & $163 \pm 10 * * *$ & $(5)$ \\
\hline $3(10 \mu \mathrm{M})$ & $95 \pm 3$ & $(26)$ & $102 \pm 2$ & $(29)$ & $78 \pm 3 * * * *$ & $(20)$ & $63 \pm 4 * * * *$ & (11) \\
\hline $4(250 \mu \mathrm{M})$ & $94 \pm 3$ & $(22)$ & $93 \pm 3$ & $(23)$ & $61 \pm 2 * * * *$ & (14) & $79 \pm 3 * * * *$ & (16) \\
\hline $5(1.5 \mu \mathrm{M})$ & $90 \pm 3 *$ & (23) & $96 \pm 2$ & $(15)$ & $90 \pm 3^{*}$ & (14) & $74 \pm 2 * * * *$ & $(23)$ \\
\hline
\end{tabular}

Migration is expressed as mean \pm standard error of the mean (SEM) of the percentage of distance traveled compared to control. Values were compared to control using a Dunnet's t-test $(*, p \leq 0.05$; $* *, \mathrm{p} \leq 0.01 ; * * *, \mathrm{p} \leq 0.005 ; * * * *, \mathrm{p} \leq 0.0001)$. 
Table S2. Normalized cell migration of PC-3 and MDA-MB-231 cells treated with hNEU inhibitors $2 \& 5$.

\begin{tabular}{|c|l|c|c|c|}
\hline & \multicolumn{2}{|c|}{ PC-3 } & \multicolumn{2}{c|}{ MDA-MB-231 } \\
\hline & Mean \pm SEM & $(\mathrm{N})$ & Mean \pm SEM & $(\mathrm{N})$ \\
\hline $\begin{array}{c}\text { Control } \\
\text { (Buffer) }\end{array}$ & $100 \pm 4$ & $(8)$ & $100 \pm 5$ & $(6)$ \\
\hline $\begin{array}{c}\text { CytoD } \\
(\mathbf{1 9 7} \mathbf{n M})\end{array}$ & $43 \pm 9^{* * * *}$ & $(7)$ & $42 \pm 5^{* * *}$ & $(7)$ \\
\hline $\mathbf{2 ( 1 0 0} \boldsymbol{\mu M})$ & $167 \pm 9^{* * * *}$ & $(7)$ & $163 \pm 10^{* * *}$ & $(8)$ \\
\hline $\mathbf{2 ( 1 0} \boldsymbol{\mu M})$ & $136 \pm 3^{* * * *}$ & $(7)$ & $157 \pm 17^{* *}$ & $(3)$ \\
\hline $\mathbf{2 ( 1} \boldsymbol{\mu M})$ & $116 \pm 3$ & $(6)$ & $138 \pm 10^{*}$ & $(5)$ \\
\hline
\end{tabular}

\begin{tabular}{|c|l|c|c|c|}
\hline & \multicolumn{2}{|c|}{ PC-3 } & \multicolumn{2}{c|}{ MDA-MB-231 } \\
\hline & Mean \pm SEM & $(\mathrm{N})$ & Mean \pm SEM & $(\mathrm{N})$ \\
\hline $\begin{array}{c}\text { Control } \\
\text { (Buffer) }\end{array}$ & $100 \pm 7$ & $(8)$ & $100 \pm 4$ & $(8)$ \\
\hline $\begin{array}{c}\text { CytoD } \\
(\mathbf{1 9 7} \mathbf{n M})\end{array}$ & $23 \pm 4^{* * * *}$ & $(8)$ & $16 \pm 2^{* * * *}$ & $(8)$ \\
\hline $\mathbf{5 ( 1 0 0} \boldsymbol{\mu M})$ & $37 \pm 7^{* * * *}$ & $(8)$ & $31 \pm 2^{* * * *}$ & $(8)$ \\
\hline $\mathbf{5 ( 2 0} \boldsymbol{\mu M})$ & $59 \pm 7^{* * * *}$ & $(8)$ & $49 \pm 4^{* * * *}$ & $(8)$ \\
\hline $\mathbf{5 ( 1 . 5} \boldsymbol{\mu M})$ & $81 \pm 1^{*}$ & $(5)$ & $81 \pm 4^{* *}$ & $(8)$ \\
\hline $\mathbf{5}(\mathbf{0 . 5} \boldsymbol{\mu M})$ & $98 \pm 1$ & $(7)$ & $95 \pm 5$ & $(8)$ \\
\hline
\end{tabular}

Migration is expressed as mean \pm standard error of the mean (SEM) of the percentage of distance traveled compared to control. Values were compared to control using a Dunnett's t-test $(*, p \leq$ $0.05 ; * *, \mathrm{p} \leq 0.01 ; * * *, \mathrm{p} \leq 0.005 ; * * * *, \mathrm{p} \leq 0.0001)$. 
Table S3. Cell migration of simultaneous inhibition of multiple hNEU enzymes in the PC-3 and MDA-MB-231 cells.

\begin{tabular}{|c|c|c|c|c|}
\hline & \multicolumn{2}{|l|}{ PC-3 } & \multicolumn{2}{|c|}{ MDA-MB-231 } \\
\hline & Mean \pm SEM & $(\mathrm{N})$ & Mean \pm SEM & $(\mathrm{N})$ \\
\hline $\begin{array}{l}\text { control } \\
\text { (Buffer) }\end{array}$ & $100 \pm 4$ & (7) & $100 \pm 8$ & (8) \\
\hline $\begin{array}{l}\text { CytoD } \\
(197 \mathrm{nM})\end{array}$ & $30 \pm 3 * * * *$ & (5) & $47 \pm 9 * * * *$ & (4) \\
\hline $2(10 \mu M)$ & $144 \pm 4 * * * *$ & $(21)$ & $161 \pm 8 * * * *$ & (12) \\
\hline $\begin{array}{c}2+4 \\
(100 \mu M+250 \mu M)\end{array}$ & $125 \pm 8^{*}$ & $(7)$ & $131 \pm 7 *$ & (6) \\
\hline $\begin{array}{c}2+5 \\
(100 \mu M+1.50 \mu M)\end{array}$ & $103 \pm 6$ & (7) & $102 \pm 6$ & (6) \\
\hline $\begin{array}{c}4+5 \\
(250 \mu \mathrm{M}+1.5 \mu \mathrm{M})\end{array}$ & $104 \pm 2$ & (6) & $116 \pm 5$ & (6) \\
\hline $\begin{array}{c}2+4+5 \\
(100 \mu M+250 \mu M+1.50 \mu M)\end{array}$ & $103 \pm 5$ & (7) & $111 \pm 9$ & (5) \\
\hline
\end{tabular}

Migration is expressed as mean \pm standard error of the mean (SEM) of the percentage of distance traveled compared to control. Values were compared to control using a Dunnett's t-test $\left(^{*}, \mathrm{p} \leq\right.$ $0.05 ; * *, \mathrm{p} \leq 0.01 ; * * *, \mathrm{p} \leq 0.005 ; * * * *, \mathrm{p} \leq 0.0001)$.

Table S4. Cytotoxicity of hNEU inhibitors.

\begin{tabular}{|c|c|c|c|c|}
\multicolumn{4}{|c}{ PC-3 } & \multicolumn{3}{c}{ MDA-MB-231 } \\
\hline $\begin{array}{c}\text { control } \\
(\text { Buffer) }\end{array}$ & $1.00 \pm 0.02$ & $(54)$ & $1.00 \pm 0.01$ & $(72)$ \\
\hline $\begin{array}{c}\mathbf{1} \\
(\mathbf{1 0 0} \boldsymbol{\mu M})\end{array}$ & $1.01 \pm 0.03$ & $(32)$ & $1.03 \pm 0.02$ & $(32)$ \\
\hline $\begin{array}{c}\text { cyto D } \\
(\mathbf{1 9 7} \mathbf{~ n M )}\end{array}$ & $0.97 \pm 0.02$ & $(16)$ & $0.90 \pm 0.02$ & $(32)$ \\
\hline $\begin{array}{c}\mathbf{2} \\
(\mathbf{1 0 0} \boldsymbol{\mu M})\end{array}$ & $0.71 \pm 0.03 * * * *$ & $(48)$ & $0.74 \pm 0.02 * * * *$ & $(32)$ \\
\hline $\begin{array}{c}\mathbf{3} \\
(\mathbf{1 0} \boldsymbol{\mu M})\end{array}$ & $0.94 \pm 0.03$ & $(32)$ & $1.05 \pm 0.02$ & $(32)$ \\
\hline $\begin{array}{c}\mathbf{4} \\
(\mathbf{2 5 0} \boldsymbol{\mu M})\end{array}$ & $1.02 \pm 0.03$ & $(36)$ & $0.99 \pm 0.02$ & $(58)$ \\
\hline $\begin{array}{c}\mathbf{5} \\
(\mathbf{1 . 5} \boldsymbol{\mu M})\end{array}$ & $1.00 \pm 0.03$ & $(15)$ & $0.97 \pm 0.01$ & $(32)$ \\
\hline
\end{tabular}

Migration is expressed as mean \pm standard error of the mean (SEM) of the percentage of distance traveled compared to control. Values were compared to control using a Dunnett's t-test $(*, \mathrm{p} \leq$ $0.05 ; * *, \mathrm{p} \leq 0.01 ; * * *, \mathrm{p} \leq 0.005 ; * * * *, \mathrm{p} \leq 0.0001)$. 
Table S5: Effect of NEU1, NEU3, and NEU4 knockdown on cell migration

\begin{tabular}{l|l|l|l|l}
\multicolumn{1}{c}{} & \multicolumn{3}{l}{ MDA-MB-231 } \\
\cline { 2 - 5 } \multicolumn{1}{c}{ (Mean \pm SEM) } & $(\mathrm{N})$ \\
\hline control & 100 & \pm & 5 & 7 \\
\hline NEU1 siRNA & 220 & \pm & $30^{* *}$ & 8 \\
\hline NEU3 siRNA & 53 & \pm & $7 * *$ & 7 \\
\hline NEU4 siRNA & 50 & \pm & $10^{* *}$ & 7 \\
\hline SC siRNA & 115 & & 5 & 5 \\
\hline
\end{tabular}

(Data shown in Fig 4)

Table S6 : Sequences of NEU3 siRNA, NEU1 siRNA, and scrambled control

Non-targeting siRNA \#1 sequence

\begin{tabular}{|l|l|}
\hline Target sequence: & UGGUUUACAUGUCGACUAA \\
\hline
\end{tabular}

NEU3 sequences

\begin{tabular}{|l|l|}
\hline Target sequence: & ACUGGAUAAUAGUGCGUAU \\
\hline Antisense: & AUACGCACUAUUAUCCAGU \\
\hline Target sequence: & CUCAUUAGGCCCAUGGUUA \\
\hline Antisense: & UAACCAUGGGCCUAAUGAG \\
\hline Target sequence: & GGGCCAUGUCACAGAGCGU \\
\hline Antisense: & ACGCUCUGUGACAUGGCCC \\
\hline Target sequence: & CUGUUUACACACCGGGAGA \\
\hline Antisense: & UCUCCCGGUGUGUAAACAG \\
\hline
\end{tabular}

NEU1 sequences

\begin{tabular}{|l|l|}
\hline Target sequence: & GGCAGCACAUGGUCUCCUA \\
\hline Antisense: & UAGGAGACCAUGUGCUGCC \\
\hline Target sequence: & AGUGAGCGAUGUUGAGACA \\
\hline Antisense: & UGUCUCAACAUCGCUCACU \\
\hline Target sequence: & GAACGACUUCGGUCUGGUG \\
\hline Antisense: & CACCAGACCGAAGUCGUUC \\
\hline Target sequence: & GAGCAAGGAUGAUGGUGUU \\
\hline Antisense: & AACACCAUCAUCCUUGCUC \\
\hline
\end{tabular}


Table S7. Glycolipid effects on cell migration.

\begin{tabular}{c|c|c|c|c|} 
& \multicolumn{3}{c}{ PC-3 } & \multicolumn{2}{c}{ MDA-MB-231 } \\
\hline & Mean \pm SEM & $(\mathrm{N})$ & Mean \pm SEM & $(\mathrm{N})$ \\
\hline $\begin{array}{c}\text { Control } \\
\text { (Buffer) }\end{array}$ & $100 \pm 5$ & $(15)$ & $100 \pm 2$ & $(12)$ \\
\hline $\begin{array}{c}\text { CytoD } \\
(\mathbf{1 9 7} \mathbf{~ n M )}\end{array}$ & $32 \pm 4$ & $(14)$ & $68 \pm 2^{*}$ & $(16)$ \\
\hline $\begin{array}{c}\text { GM3 } \\
\mathbf{( 5 0} \mathbf{~ n g / m L )}\end{array}$ & $73 \pm 7^{*}$ & $(16)$ & $124 \pm 16$ & $(13)$ \\
\hline $\begin{array}{c}\text { Lac-Cer } \\
(\mathbf{5 0} \mathbf{~ n g / m L )}\end{array}$ & $130 \pm \mathbf{7}^{*}$ & $(14)$ & $150 \pm 11^{* *}$ & $(14)$ \\
\hline
\end{tabular}

Migration is expressed as mean \pm standard error of the mean (SEM) of the percentage of distance traveled compared to control. Values were compared to control using a Dunnett's t-test $\left(^{*}, \mathrm{p} \leq\right.$ $0.05 ; * *, \mathrm{p} \leq 0.01 ; * * *, \mathrm{p} \leq 0.005 ; * * * *, \mathrm{p} \leq 0.0001)$. 

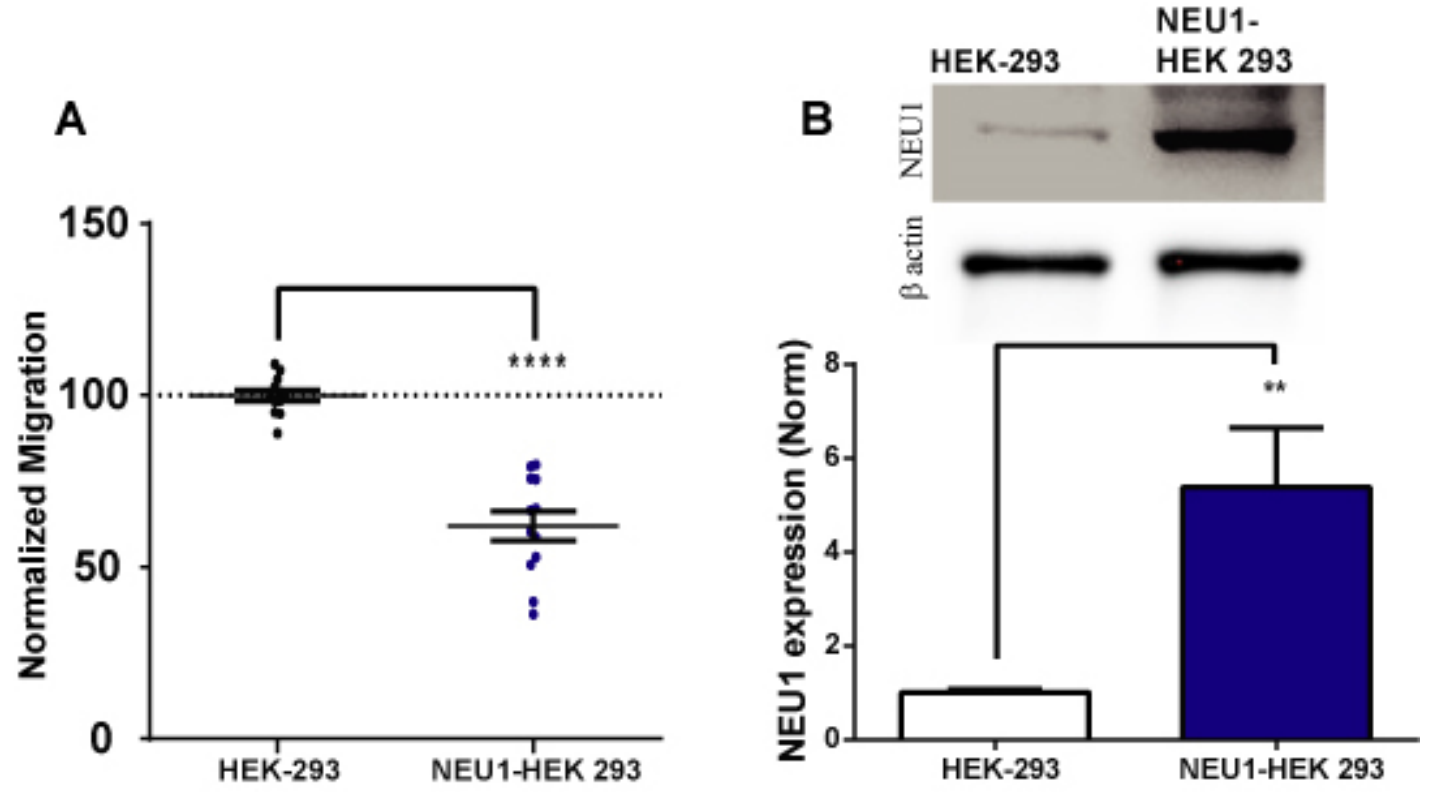

Figure S1. Effect of NEU1 overexpression on HEK 293 cell migration.

The NEU1 isoenzyme was overexpressed in HEK293 cell lines using a previously described method. ${ }^{l}$ A) Overexpression of NEU1 caused a significant decrease in the migration of HEK293 cell lines. B) Expression levels of NEU1 in control and transfected HEK293 cell lines were tested using western blotting. A single representative image from at least six blots for NEU1 is shown (top). Data from all blots are shown in the bar graph. The amount of enzyme was corrected to a $\beta$ actin loading control and normalized to control cells. Data are plotted as the mean $\pm \mathrm{SEM}$ and compared to control using a student's t-test $\left(^{*}, \mathrm{p} \leq 0.05 ; * *, \mathrm{p} \leq 0.01 ; * * *, \mathrm{p} \leq 0.005 ; * * * *, \mathrm{p} \leq\right.$ 0.0001). 

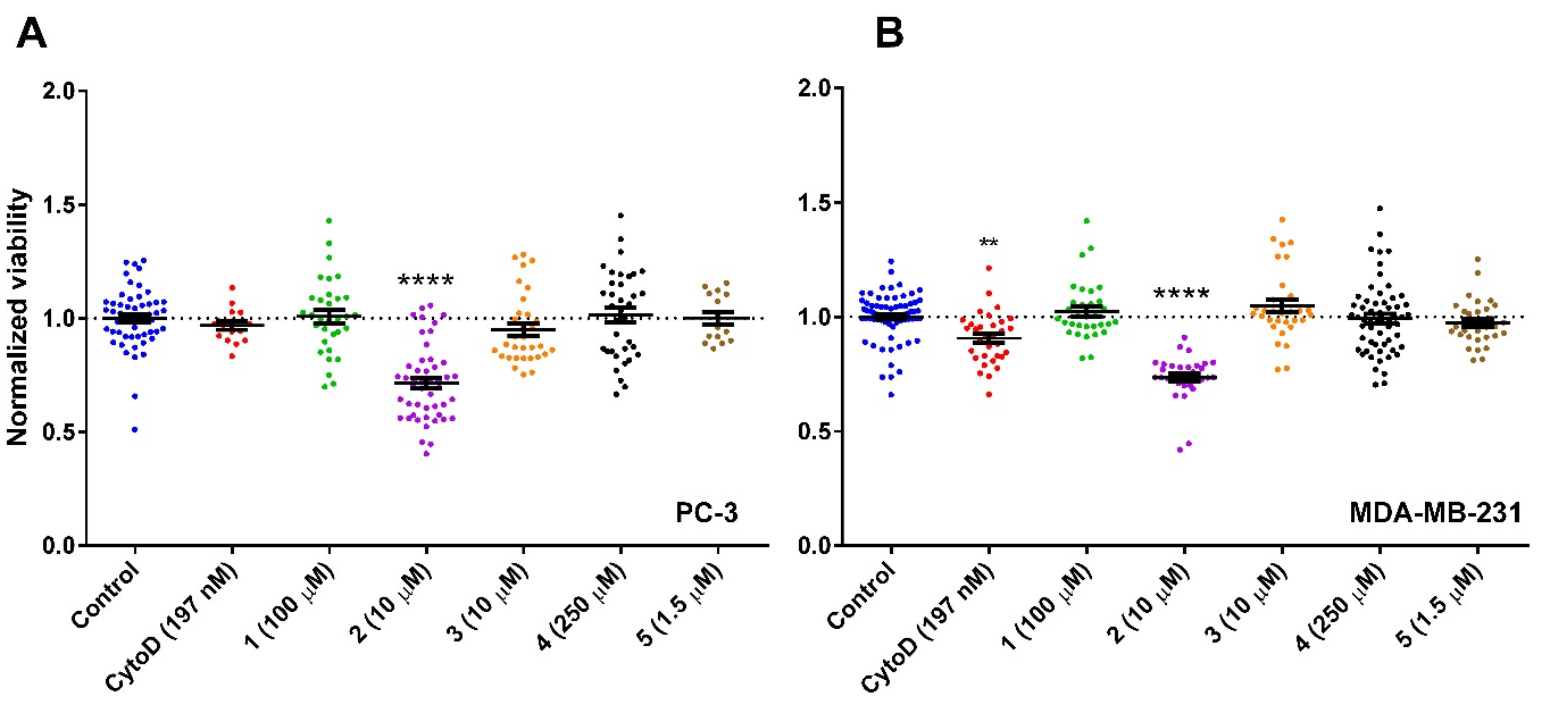

\section{Figure S2. Toxicity profile of the PC-3 and MDA-MB-231 cells with inhibitors.}

A) PC-3 cells. B) MDA-MB-231 cells were treated with the highest concentrations of inhibitors used for migration studies and assessed for viability. For each cell line, $2.5 \mathrm{x} 10^{4}$ cells were incubated in each well of a clear 96 plate in the presence of inhibitors for $18 \mathrm{~h}$. After incubation, $20 \mu 1$ of MTS solution was added to each well and incubated for 1 hour. The absorbance of soluble formazan product was measured at $490 \mathrm{~nm}$ using a plate reader (Molecular devices). Data are plotted as the mean \pm SEM and compared to control using a Dunnett's t-test $(*, p \leq 0.05 ; * *, p \leq$ $0.01 ; * * *, \mathrm{p} \leq 0.005 ; * * * *, \mathrm{p} \leq 0.0001)$. 

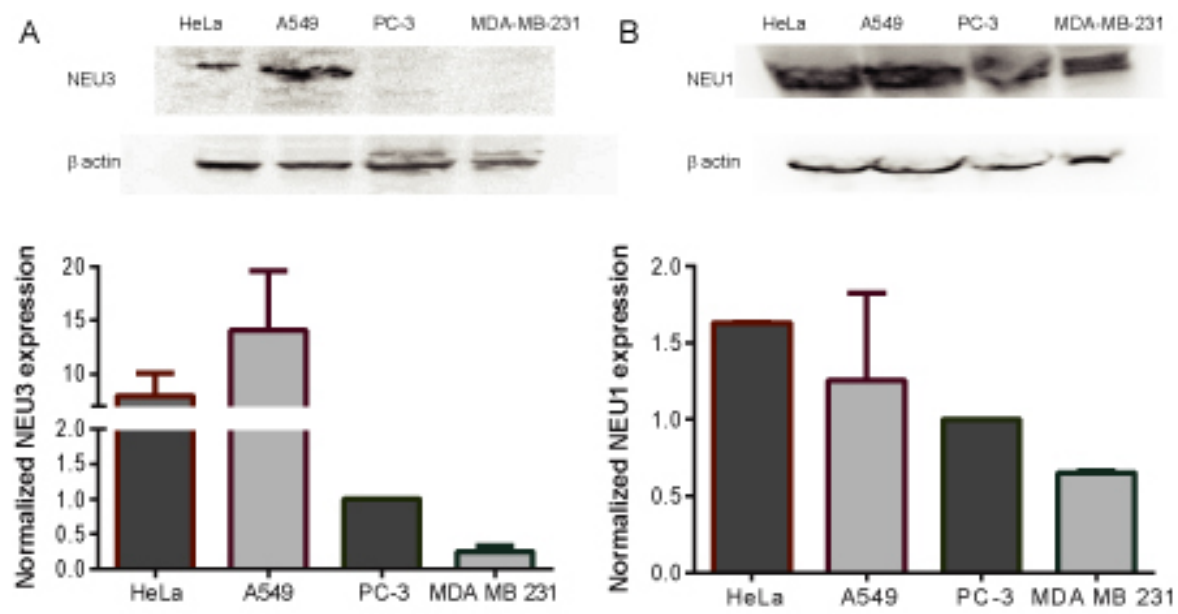

Figure S3. Differential expression levels of NEU3 and NEU1 enzymes.

NEU expression levels in HeLa, A549, PC-3, and MDA-MB-231 cell lines were determined using western blotting using mouse anti-human monoclonal antibodies for A) NEU3 (MBL international, clone 11B) and B) NEU1 (abcam, clone EPR15712). An image from a single representative blot is shown for each enzyme (top). At least two experiments were performed for each cell line and the results are summarized in the lower bar graph. The amount of enzyme expression was corrected to a $\beta$-actin loading control and normalized to that of PC-3 cells and plotted as mean \pm SEM. 

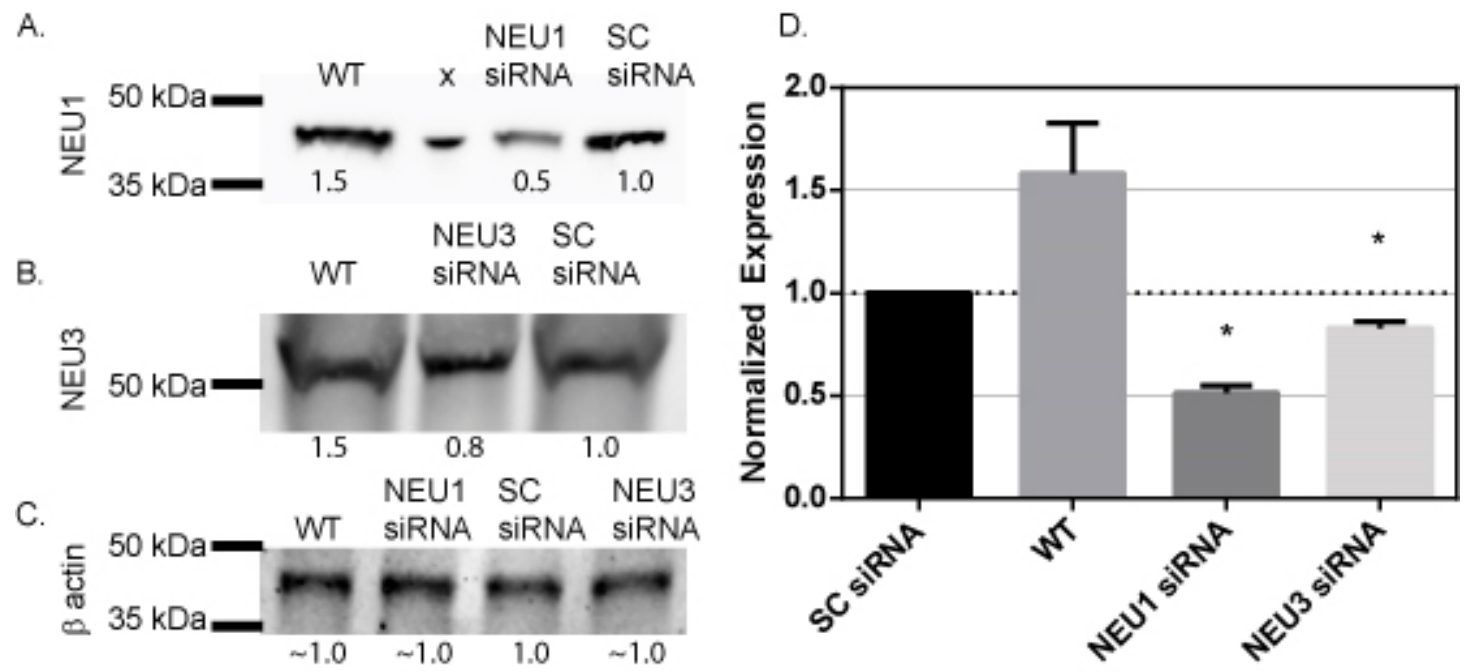

Figure S4: siRNA Knockdown of NEU1 and NEU3 enzymes in MDA-MB-231 cells.

Representative western blots for (A) NEU1, (B) NEU3, and (C) beta actin (loading control) on MDA-MB-231 cells after treatment with siRNA and controls. Analysis of siRNA knockdown efficiency of NEU1 siRNA and NEU3 siRNA is presented in panel (D), showing $20 \%$ reduced expression of NEU3 and $\sim 50 \%$ reduced expression of NEU1. Expression levels were compared to that of the scrambled control (SC siRNA) group. The data is presented as mean $\pm \mathrm{SEM}$, and conditions were compared to control using one-way ANOVA and Dunnett's t-test $(*, p \leq 0.05)$. See Figure S5 for full image of the blots used in panels A \& B. In panel A, the lane labeled "x" was an incompletely loaded lane. 


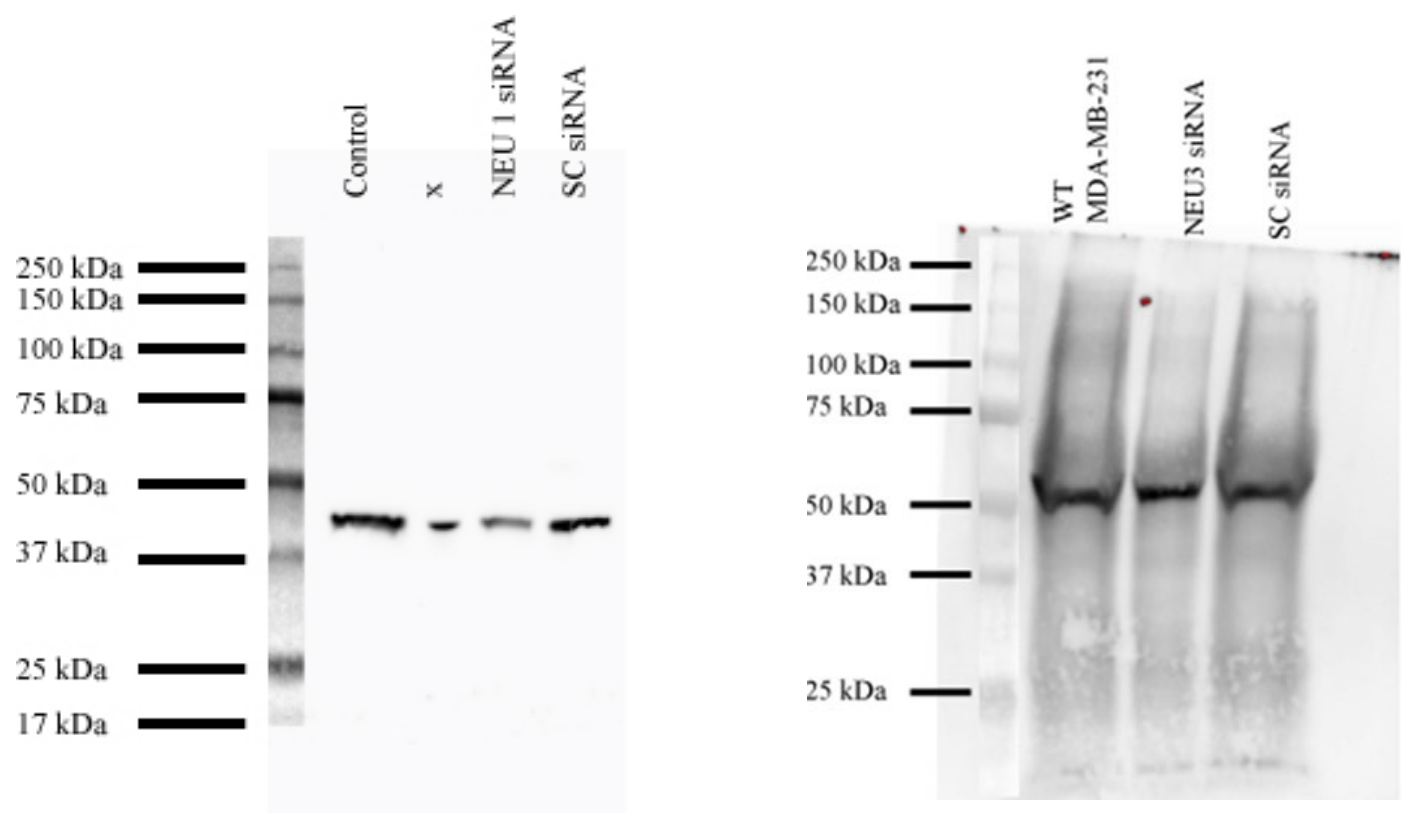

Figure S5: siRNA Knockdown, NEU1 and NEU3 expression levels.

Representative western blots of (left) NEU1 and (right) NEU3 knockdown in MDA-MB-231. The cells were treated with the indicated siRNA for $72 \mathrm{~h}$ in serum reduced conditions in DMEM (see Table S5). Lysates were collected and equal amount of protein $(\sim 10 \mu \mathrm{g})$ was loaded on SDS-PAGE gel. The blots were developed using mouse anti-human NEU1 or NEU3 antibody as primary and HRP conjugated goat anti-mouse antibody as secondary. 


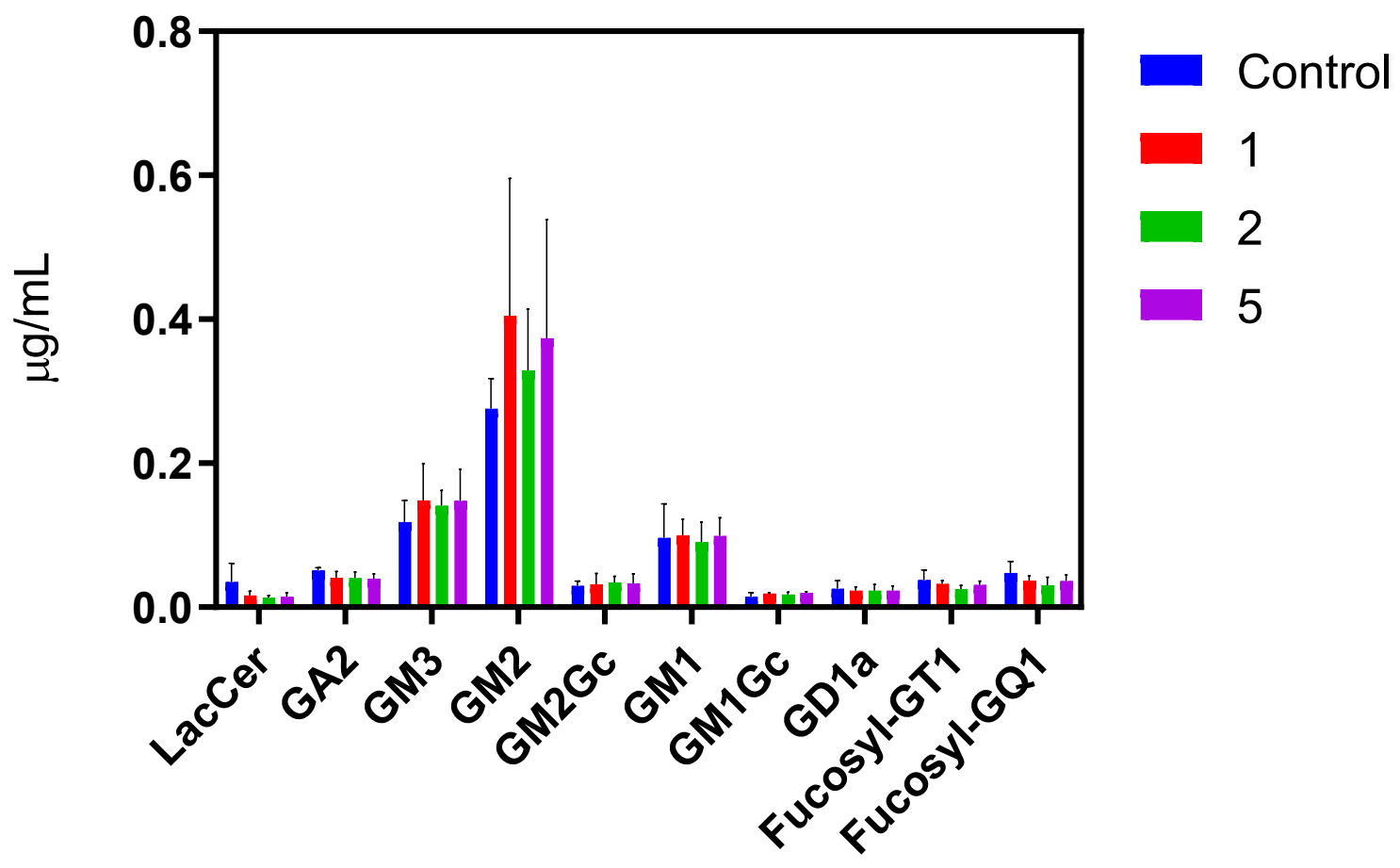

Figure S6. Glycolipid analysis of PC-3 cells treated with specific inhibitors.

Cultured PC-3 cells were treated with neuraminidase inhibitors 1, 2, and 5 for $21 \mathrm{~h}$. After that cells were harvested, lysed, and glycolipids were purified using protocol described in experimental methods. Gangliosides were treated with EGCase, followed fluorescent labeling of released oligosaccharides with 2AA. The labeled glycans were then analyzed by LC-MS (Agilent 6220 Accurate-Mass TOF HPLC/MS) and assigned using their corresponding mass by Agilent MassHunter Qualitative software. Data were compared to the amounts of each glycan present in control group using the student's t-test and plotted as the mean $\pm \operatorname{SEM}(\mathrm{N}=3 ; *, \mathrm{p} \leq 0.05 ; * *, \mathrm{p} \leq$ $0.01 ; * * *, \mathrm{p} \leq 0.005 ; * * * *, \mathrm{p} \leq 0.0001)$. 

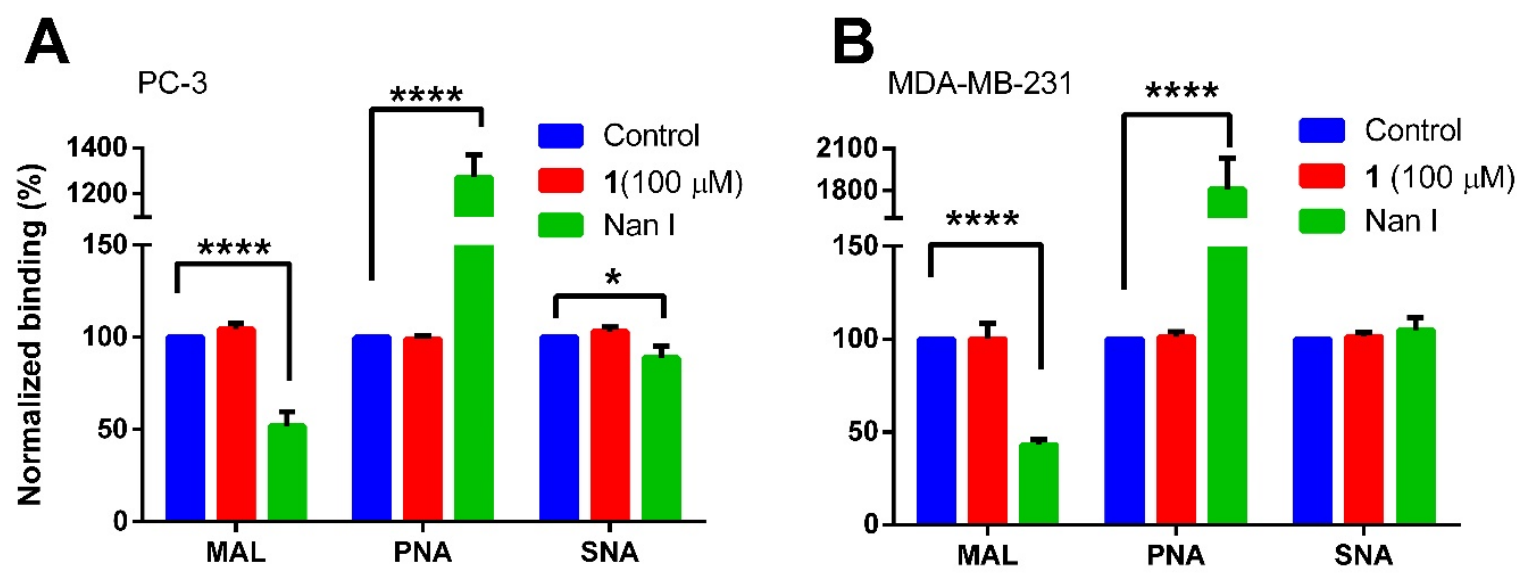

Figure S7: Changes in cell surface sialic acid content by lectin staining.

A) PC-3 or B) MDA-MB-231 cells were treated with buffer or DANA (100 $\mu \mathrm{M}, 18 \mathrm{~h})$. Cells were then detached (10 mM EDTA for $2 \mathrm{~h}$ in PBS) and harvested. For NanI treatment, cells were treated with 0.1 RU NanI for $2 \mathrm{~h}$ after harvesting. 1 x $10^{5}$ cells were then stained with Peanut agglutinin (PNA, conjugated with Alexa Fluor 647, $20 \mu \mathrm{g} / \mathrm{mL}$ ) or with Sambucus nigra agglutinin (SNA, conjugated with FITC, $20 \mu \mathrm{g} / \mathrm{mL}$ ) or with Maackia amurensis lectin (MAL, conjugated with FITC, $5 \mu \mathrm{g} / \mathrm{mL}$ ) for 30 mins separately. Fluorescence signal from MAL, PNA, or SNA staining was detected using flow cytometry, and normalized to the control group. Data are plotted as the mean \pm SEM and compared to control using a student's t-test $\left(^{*}, \mathrm{p} \leq 0.05 ; * *, \mathrm{p} \leq 0.01 ; * * *, \mathrm{p} \leq 0.005\right.$; $* * * *, \mathrm{p} \leq 0.0001)$. 


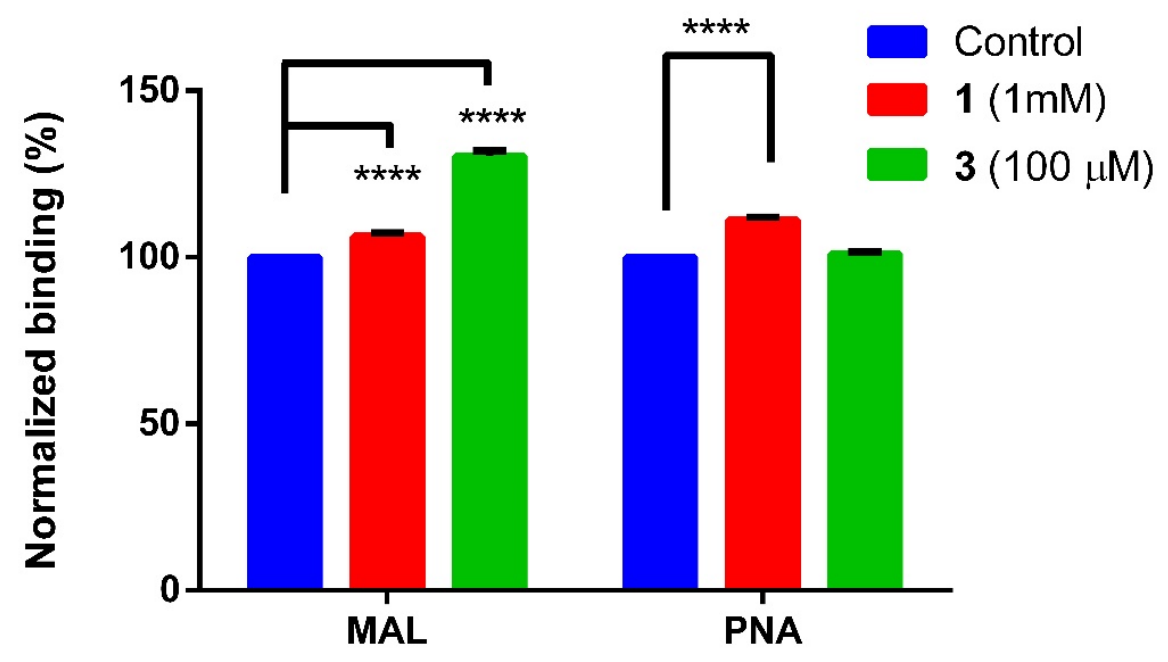

Figure S8. Changes in cell surface sialic acid content of MDA-MB-231 cells at high inhibitor concentrations.

MDA-MB-231 cells were treated with DANA $1(1 \mathrm{mM})$ and zanamivir $3(100 \mathrm{mM})$ for $18 \mathrm{~h}$. Cells were then detached (10 mM EDTA for $2 \mathrm{~h}$ in PBS) and harvested. For NanI treatment, cells were treated with $0.1 \mathrm{RU}$ NanI for $2 \mathrm{~h}$ after harvesting. $1 \times 10^{5}$ cells were then stained with Peanut agglutinin (PNA, conjugated with Alexa Fluor 647, $20 \mu \mathrm{g} / \mathrm{mL}$ ) or with Maackia amurensis lectin (MAL, conjugated with FITC, $5 \mu \mathrm{g} / \mathrm{mL}$ ) for 30 mins separately. Fluorescence signal from MAL or PNA staining was detected using flow cytometry, and normalized to the control group. Data are plotted as the mean \pm SEM and compared to control using a student's t-test $\left({ }^{*}, \mathrm{p} \leq 0.05 ;{ }^{* *}, \mathrm{p} \leq\right.$ $0.01 ; * * *, \mathrm{p} \leq 0.005 ; * * * *, \mathrm{p} \leq 0.0001)$.

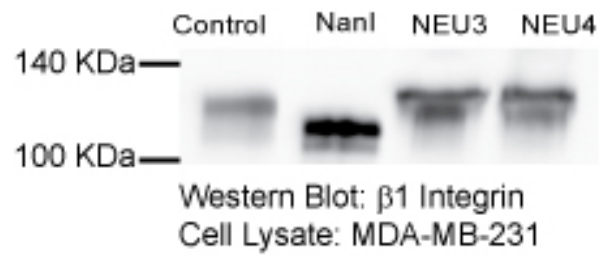

Figure S9: Molecular weight of the $\beta 1$ integrin after neuraminidase treatment.

MDA-MB-231 cells were treated with NanI or NEU3 for $3 \mathrm{~h}$; and NEU4 for $1 \mathrm{~h}$. Cells were lysed and the molecular weight of the $\beta 1$ integrin was determined using a western blot using rabbit antiintegrin beta 1 antibody (EP1041Y) from Abcam, USA at 1:2000 dilution. Two separate experiments were performed, and a representative image is shown. 


\section{References:}

1. Pshezhetsky, A. V., and Potier, M. (1996) Association of N-Acetylgalactosamine-6-sulfate Sulfatase with the Multienzyme Lysosomal Complex of $\beta$-Galactosidase, Cathepsin A, and Neuraminidase: POSSIBLE IMPLICATION FOR INTRALYSOSOMAL CATABOLISM OF KERATAN SULFATE, Journal of Biological Chemistry 271, 28359-28365. 